\title{
The Influence of Service Quality, Tuition Fee and Promotion on Student Decisions to Continue Study in Postgraduate of Prima Indonesia University
}

\author{
Regina Fortunata ${ }^{1}$, Nagian Toni' ${ }^{2}$ \\ ${ }^{1}$ Master of Management, Universitas Prima Indonesia, Indonesia \\ ${ }^{2}$ Lecturer, Universitas Prima Indonesia, Indonesia \\ toni.mul@gmail.com
}

\begin{abstract}
The Prima Indonesia University (UNPRI) Postgraduate School is one of the Postgraduate programs in Medan. Various efforts to maintain and improve service quality have been made, as well as tuition fees have been set within an affordable and competitive range, as well as intense promotion, however these efforts have not succeeded in increasing the number of UNPRI Postgraduate School students, instead they have decreased each year. The purpose of this study is to find the factors that cause the low number of student registrants and develop alternative strategies and policies that can be implemented by management. UNPRI School to increase the number of student registrants through quality service, tuition fees, and promotions. This type of research is survey research. The questionnaire was distributed by clustered random sampling to 89 active students at the UNPRI Postgraduate School. From the results of the analysis, it was found that $42.7 \%$ of the decisions of students registering to continue their studies at the UNPRI Postgraduate School were influenced by Service Quality, Tuition, and Promotion, while 57.3\% were influenced by other variables outside the variables used in this study. Service quality variables, tuition fees, and promotions together significantly influence student decisions. However, based on partial testing, the variable tuition does not significantly affect student decisions. On the contrary, service quality and promotion variables have a significant effect partially on student decisions.
\end{abstract}

Keywords

service quality;

tuition; promotion;

student decisions

\section{Introduction}

Universitas Prima Indonesia or better known as UNPRI is one of the tertiary institutions in North Sumatra. UNPRI offers 33 (thirty-three) study programs, including 7 (seven) study programs at the master's level (S-2).

At present active students who are pursuing undergraduate education at UNPRI number around 10,000 students each year, with a total of 4,000 graduates each year. Thus, there is a huge opportunity for the Graduate School to get customers, namely graduates of undergraduate programs who intend to continue their education to a higher level (S2). 
The decision of prospective students to continue their studies at a university is influenced by many factors. Kelvin (2018) argues that the cost of study, promotion, lecture facilities, and service quality influence the decision of prospective students to choose the university where they continue their studies

Promotion has a significant effect on student decisions (Kalsum, 2008). Various promotional efforts have been made by the management of UNPRI to disseminate all study programs available at UNPRI and all its advantages.

These efforts include giving tuition discounts, holding workshops related to the skills and expertise needed in the world of work, national seminars, international seminars, book review. Cooperation with various companies, as well as the use of various electronic / internet media.

The perception of the cost of education affects the interest in continuing study at a university. When there is an increase in the cost of education, there will be a decrease in interest in continuing studies (Karyati, 2016). At UNPRI, the tuition fees charged are quite competitive. Registrants are only subject to an initial registration fee of two million two hundred and fifty thousand rupiahs (including registration fees, alma mater suits, and matriculation fees), and tuition fees per semester of seven million five hundred thousand rupiahs.

Various efforts to promote and determine competitive tuition fees at the UNPRI Postgraduate School did not succeed in increasing the number of applicants to the UNPRI Postgraduate School, even what happened was a decrease in registrants in 2018 (third year running), as seen in It is known that the number of registrants in the second year is consolidation experienced a significant increase of 254\%. This is due to the addition of 2 (two) new study programs opened in the second year, each of which absorbed more than 100 registrants. However, if reviewed per study program, it can be seen that there are 3 (three) study programs that have decreased registrants, namely Management Study Program, Law Study Program, and Indonesian Language Education Study Program, and the most significant decline occurred in Indonesian Language Education Study Program, namely down by $40 \%$. However, there are also study programs that have increased registrants, namely the Accounting Study Program and the Notary Study Program.

Conditions In the third year (2018) different from the second year, where on a consolidated basis there was a decrease in registrants by $37 \%$. The largest percentage decline (y o y) occurred in the Law Study Program and the Accounting Study Program. Study programs that are always experiencing a decrease in registrants every year, namely Management Study Program, Law Study Program, and Indonesian Language Education Study Program.

Therefore the previous study about affecting had written by Factors Romdonny (2019) with entitled Affecting Customer Loyalty in Product. The result shows that customer loyalty can be formed from the commitment of the management of business organizations to provide the best for consumers, especially related to product quality, competitive prices, and satisfying services. However, several obstacles faced by business organizations include high raw materials, and capital. Therefore, the role of the government is highly expected by business actors, especially related to the import policy of raw materials which is considered very burdensome to producers.

Quality of service also plays an important role in attracting undergraduate graduates to register. Arief (2007) states that customers are increasingly skilled in their requests and increasingly demanding higher service standards. If the service quality felt by students during 
the lecture is satisfactory, then directly or indirectly, the image of the service will be widespread because the satisfaction felt by students and graduates will be conveyed to students and prospective students in a chain. Based on observations made, there were several complaints from students about the quality of service received, including the inconsistency or uncertainty of lecture schedules, where lecture schedules often experience sudden changes and cancellations. This is very confusing and detrimental to students. Other complaints raised by students are about the quality of lecturers who teach, namely in terms of lecture material that is too theoretical and not practical and how to teach that is monotonous, one-way (not interactive) and less interesting. Quality of service like this certainly has an unfavorable impact on the image of UNPRI services in the eyes of prospective Postgraduate students and in the long run can reduce UNPRI's competitiveness.

\subsection{The problem of study}

From the results of the identification of the problems above, the researchers formulated the problems that occurred namely:

1. Is there an influence simultaneously on the quality of service, cost and promotion on the decision of students to continue their studies at the Graduate School of the University of Prima Indonesia.

2. Is there an influence on the quality of service on the decision of students to continue their studies at the Graduate School of the University of Prima Indonesia.

3. Is there a cost effect on the decision of students to continue their studies at the University of Indonesia Graduate School.

4. Is there any influence of promotion on the decision of students to continue their studies at the Graduate School of the University of Prima Indonesia.

\section{Research Method}

\subsection{Definition of Service Quality}

According to Zeithaml et al in Laksana (2008), service quality can be defined as "The extent of discrepancy between customers' expectations or desires and their perceptions". From this statement stated the difference between the expectations or desires of consumers with their level of perception.

According to Lovelock (2011), service quality is the result of an evaluation process in which customers compare their perception of service and results with what they expect.

According to Wyekof in Arief (2007), service quality is the level of perfection expected and control of perfection is to meet customer desires.

\section{a. Benefits and Objectives of Service Quality}

According to Soedjas (2014), one of the benefits of service quality is to create an unforgettable experience that will give its own impression in the hearts of customers.

According to Soedjas (2014), the ultimate goal of service quality is to make loyal customers or become loyal customers, then to do repeat action, not just action.

\subsection{Definition of Cost}

According to Alma (2007), the cost is any sacrifice to make an item or to obtain an item, which is economically rational. So in this sacrifice may not contain elements of waste, because all waste including the element of loss, is not charged to the basic costs.

According to Gitosudarmo in Sunyoto (2012), the definition of cost is the amount of money needed to obtain a certain number of products or a combination of goods and services. 
The true cost is not only for a product that is being traded in the market but also applies to other products.

According to Malau (2016), costs are a basic measure of an economic system because costs affect the allocation of factors of production. In its role as a determinant of the allocation of scarce resources, costs determine what must be produced (supply) and who will get how much goods or services are produced (demand).

According to Tjiptono (2007), costs are monetary units or other measures (including other goods and services) exchanged in order to obtain ownership or use rights of an item or service.

\section{b. Benefits and Cost Objectives}

Lupiyoadi (2014), cost also plays an important role in communicating the quality of the service. In the absence of tangible cues, consumers associate high costs with high levels of service product performance.

\section{c. Cost Indicators}

According to Stanton (1998) indicators that characterize the costs used in this study, namely:

1. Affordability of costs

2. Conformity of cost with product quality

3. Cost competitiveness

4. The suitability of costs with benefits

\subsection{Definition of Promotion}

According to Laksana (2008), promotion is a communication from the seller and buyer originating from the right information that aims to change the attitudes and behavior of the buyer, which previously did not change the attitudes and behavior of the buyer, who had not known to become acquainted so as to become a buyer and keep in mind the product.

According to Gitosudarmo in Sunyoto (2012), promotion is an activity aimed at influencing consumers so that they can become familiar with the products offered by the company to them and then they become happy and buy the product.

\section{Factors Affecting Promotion}

Factors that influence the promotional mix according to Sunyoto (2012), namely:

1. Nature of the Market

2. Product Properties

3. Product life cycle

4. Available funds

\subsection{Definition of Consumer Decisions}

According to Kotler and Keller (2013), purchasing decisions are actions of consumers to want to buy or not to product. Meanwhile, according to Nitisusastro (2012), consumer decisions are the final stages of a series of processes that occur in consumer behavior.

According to Sumarwan (2004), a purchasing decision is a decision as the choice of an action from two or more alternative choices.

The same is explained by Setiadi (2003) consumer decision making is an integration process that combines knowledge to evaluate two or more alternative behaviors and choose one of them. 


\section{Consumer Decision Indicators}

According to Lamb (2001), when buying products in general consumers follow 5 (five) stages of the process, namely:

1. Introduction of Needs

2. Search for information

3. Alternative evaluation

4. Purchase

5. Post-purchase behavior

\subsection{Conceptual Framework}

The conceptual framework shows the logical relationship between factors or variables that have been stated in the theoretical basis and identified its importance for use in problem analysis.

Based on the theoretical basis in the previous chapter, independent and dependent variables have been identified. Thus, a conceptual framework can be built as follows:

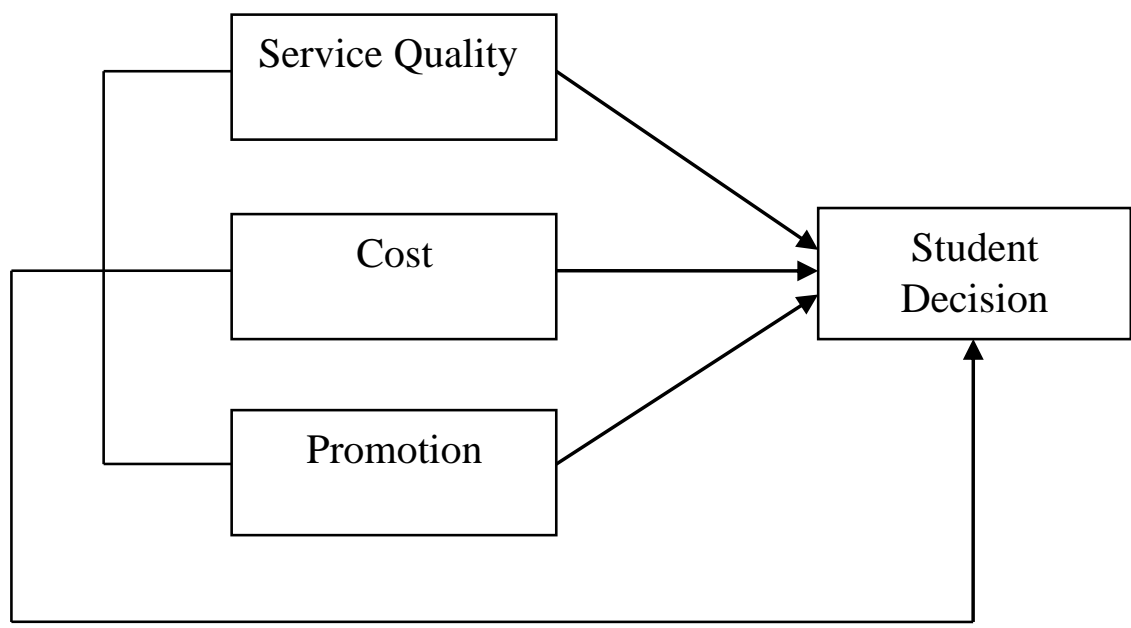

Figure 2.1 Conceptual Framework

\subsection{Hypothesis}

Hypothesis is a statement of logical relationship between two or more variables that are shown in a quantitative form so that the truth of the statement can be tested. The results of the hypothesis provide answers to the phenomena whose truth will be tested. The formulation of the hypothesis is determined and derived from the conceptual framework because all the patterns of logical relationships between the variables have been spelled out in a conceptual framework which also shows that the type of hypothesis being carried out is an associative hypothesis.

Based on the conceptual framework above, the hypotheses in this study are:

1. Quality of service, cost and promotion simultaneously influence the decision of students to continue their studies at the Graduate School of the University of Prima Indonesia.

2. Quality of service affects the decision of students to continue their studies at the University of Indonesia Graduate School.

3. Costs affect the decision of students to continue their studies at the University of Indonesia Graduate School.

4. Promotion affects the decision of students to continue their studies at the University of Indonesia Graduate School. 


\section{Research Method}

\subsection{Types of Research}

This type of research is survey research. Survey research is research conducted on large and small populations, but the data studied are data from samples taken from these populations, so that relative events, distribution, and relationships between variables are found (Sugiyono, 2008).

\subsection{Samples}

Because the research was conducted in seven study programs, clustered random sampling was used for sampling in this study, namely by taking representatives from each cluster / group contained in the population, from which each cluster / group of samples was taken randomly. The sample size is determined proportionally based on the number of active students per Study Program.

Determination of sample size in this study was carried out using the Slovin formula (Sugiyono, 2008):

$$
\begin{aligned}
& n=\frac{765}{1+765(0,1)^{2}} \\
& n=\frac{765}{8,65} \\
& n=88,43 \text { (Rounded to } 89 \text { people) }
\end{aligned}
$$

In accordance with the above calculation, the sample size in this study was 89 people by dividing the sample into 7 (seven) groups based on the Study Program.

Proportional sampling per Study Program can be seen in Table 1.

Table 1. Population and Research Samples

\begin{tabular}{|l|c|c|c|c|}
\hline No. & Study program & $\begin{array}{c}\text { Population } \\
(\text { People })\end{array}$ & $\begin{array}{c}\text { Percentage } \\
(\%)\end{array}$ & $\begin{array}{c}\text { Sample } \\
(\text { People })\end{array}$ \\
\hline 1. & S2 in Biomedical Science & 263 & 34 & 31 \\
\hline 2. & S2 Public Health & 226 & 30 & 26 \\
\hline 3. & S2 in Management & 77 & 10 & 9 \\
\hline 4. & S2 in Accounting & 74 & 10 & 9 \\
\hline 5. & S2 Notary & 53 & 7 & 6 \\
\hline 6. & S2 in Law & 41 & 5 & 5 \\
\hline 7. & S2 Indonesian Language Education & 31 & 4 & 4 \\
\hline \multicolumn{2}{|c|}{ Total } & 765 & 100 & 89 \\
\hline
\end{tabular}

Source: Prima Indonesia University

\section{Result and Discussion}

\subsection{Simultaneous Hypothesis Test Results (Test F)}

This test is used to determine whether the independent variables (X1, X2, and X3) together or simultaneously significantly influence the dependent variable (Y) or to find out whether the regression model can be used to predict the dependent variable or not as shown in Table 2: 
Table 2. Test Results

\begin{tabular}{|l|c|c|c|c|c|}
\hline Model & Sum of Squares & df & Mean Square & F & Sig \\
\hline 1 Regression & 141,805 & 3 & 47,268 & 22,897 &, $000^{\mathrm{a}}$ \\
Residual & 175,475 & 85 & 2,064 & & \\
Total & 317,281 & 88 & & & \\
\hline
\end{tabular}

The F-count value in Table 4.1 is 22.889 while the F-table value with $(0.05$; df1; df 2$)$ is $(0.05 ; 3 ; 85)$ the F-table value $=2.712$, because the F-count value $>\mathrm{F}$-table $(22,897>2,712)$, then Ho is rejected and $\mathrm{H} 1$ is accepted. That is, there is a significant relationship simultaneously or jointly between Service Quality, Tuition, and Promotion of Student Decisions.

\subsection{Partial Hypothesis Test Results (t Test)}

This test is used to determine whether in the regression model independent variables (X1, X2, and X3) partially significantly influence the dependent variable (Y). $\mathrm{T}$ test results can be seen in Table 3:

Table 3. Test Results $\mathrm{t}$

\begin{tabular}{|c|c|c|c|c|c|c|}
\hline & \multirow[t]{2}{*}{ Model } & \multicolumn{2}{|c|}{ Unstandardized Coefficients } & \multirow{2}{*}{$\begin{array}{c}\begin{array}{c}\text { Standardized } \\
\text { Coefficients }\end{array} \\
\text { Beta }\end{array}$} & \multirow[t]{2}{*}{$\mathrm{t}$} & \multirow[t]{2}{*}{ Sig. } \\
\hline & & $B$ & Std. Error & & & \\
\hline 1 & $\begin{array}{l}\text { (Constant) } \\
\text { X1 } \\
\text { X2 } \\
\text { X3 }\end{array}$ & $\begin{array}{r}6,058 \\
, 067 \\
, 064 \\
, 300\end{array}$ & $\begin{array}{r}1,254 \\
, 016 \\
, 094 \\
, 099\end{array}$ & $\begin{array}{l}\text {,435 } \\
\text {,064 } \\
\text { 290 }\end{array}$ & $\begin{array}{r}4,829 \\
4,344 \\
, 677 \\
3,020\end{array}$ & $\begin{array}{l}, 000 \\
, 000 \\
, 500 \\
, 003\end{array}$ \\
\hline
\end{tabular}

Based on Table 3 the following results are obtained:

1. Table of distribution of $\mathrm{t}$ at $\alpha=5 \%$ with degrees of freedom (df) $=\mathrm{n}-\mathrm{k}-1$, where $\mathrm{n}$ is the number of samples and $\mathrm{k}$ is the number of independent variables, obtained value $\mathrm{df}=$ $89-3-1=85$, so the value of $t$ table of 1,988 .

2. From the SPSS output, the X1 variable t-count is 4,344, X2 is 0,677 , and $\mathrm{X} 3$ is 3,020 .

3. For variable $\mathrm{X} 1$, the value of $\mathrm{t}$-count $>\mathrm{t}$-table with a Sig value less than 0.05 , then Ho is rejected and $\mathrm{H} 1$ is accepted, meaning that partially or individually there is a significant influence between the $\mathrm{X} 1$ variable on the $\mathrm{Y}$ variable.

4. For variable $\mathrm{X} 2$, the value of $\mathrm{t}$-count $<\mathrm{t}$-table with a Sig value less than 0.05 , then Ho is accepted and $\mathrm{H} 1$ is rejected, meaning that partially or individually there is no significant influence between the $\mathrm{X} 2$ variable on the variable $\mathrm{Y}$.

5. For variable $X 3$, the value of $t$-count $>t$-table with a Sig value less than 0.05 , then Ho is rejected and $\mathrm{H} 1$ is accepted, meaning that partially or individually there is a significant influence between the $\mathrm{X} 3$ variable on the $\mathrm{Y}$ variable.

\subsection{Effect of Service Quality on Student Decisions}

The value of $t$-count $>t$-table with Sig value less than 0.05 , then Ho is rejected and H1 is accepted, meaning that partially or individually there is a significant influence between the variable Service Quality on the Student Decision variable. Service Quality has a significant influence on Student Decisions in choosing a Graduate School as a place to continue their studies. This means that the quality of service is increasingly reliable, the more it gives a sense of security / assurance to students, the more understanding of the situation of students as customers, and the better the facilities and the more responsive service can improve the 
decision of undergraduate graduates to continue their education at the UNPRI Postgraduate School.

\subsection{Effects of Tuition Costs on Student Decisions}

The value of $\mathrm{t}$-count $<\mathrm{t}$-table with Sig value is less than 0.05 , then Ho is accepted and $\mathrm{H} 1$ is rejected, meaning that partially or individually there is no significant effect between the variable tuition variable to the student decision variable. Tuition fees do not have a significant influence on Student Decisions in choosing a Graduate School as a place to continue their education. The tuition fees imposed by UNPRI are considered to be very affordable and in accordance with the quality of lecture services received and are very competitive when compared to the Postgraduate Program at other universities in Medan. However, the results of this study indicate that although students consider affordable tuition fees, in accordance with the service and competitive, students will not necessarily show a positive attitude towards the selection of the UNPRI Postgraduate School as a place to continue their education.

\subsection{Effect of Promotion on Student Decisions}

The value of t-count> t-table with a Sig value less than 0.05 , then Ho is rejected and $\mathrm{H} 1$ is accepted, meaning that partially or individually there is a significant influence between the Promotion variable on the Student Decision variable. Promotion has a significant influence on Student Decisions in choosing a Graduate School as a place to continue their education. Various promotional efforts undertaken by UNPRI such as direct presentations, discounts / cuts in tuition fees, and socialization events have made undergraduate graduates aware of the existence of the UNPRI Postgraduate School and certainly related to their decision to choose the UNPRI Postgraduate School as a place to continue their education.

\subsection{Effect of Service Quality, Tuition, and Promotion Together - Together Against Student Decisions}

The results of statistical data analysis showed that the Student's decision to choose the UNPRI Postgraduate School was influenced by Service Quality, Tuition and Promotion, Based on an analysis of the questionnaire distributed to 89 respondents, a coefficient of determination (R Square) of 0.427 was obtained, which means that Service Quality, Tuition and Promotion Costs are able to explain $42.7 \%$ of changes in Student Decision variables and the remaining $57.3 \%$ are influenced by other factors not examined in this study.

\section{Conclusions}

Based on the results of research and discussion in the previous chapter it can be concluded as follows:

1. Service Quality, Tuition, and Promotion together influence the Student's decision to choose the UNPRI Postgraduate School.

2. Service Quality influences the Students' Decision to choose the UNPRI Postgraduate School.

3. Tuition fees do not affect the Students' decision to choose the UNPRI Postgraduate School.

4. Promotion influences the Students' decision to choose the UNPRI Postgraduate School. 


\section{References}

Adam, Muhammad. (2015). Manajemen Pemasaran Jasa. Bandung : Alfabeta.

Alma, Buchari. (2007). Manajemen Pemasaran dan Pemasaran Jasa. Edisi Revisi : CV Alfabeta.

Arief. (2007). Pemasaran Jasa \& Kualitas Pelayanan. Malang : Bunyumedia Publishing.

Herlambang, Susatyo. (2014). Basic Marketing (Dasar-dasar Marketing) Cara Mudah Memahami IlmuPemasaran. Yogyakarta : Gosyeng Publishing.

Kalsum, Eka Umi. (2008). Analisis Pengaruh Strategi Bauran Pemasaran terhadap Keputusan MahasiswaMemilih Fakultas Ekonomi Universitas Al-Azhar Medan. Tesis. Universitas Sumatera Utara.

Karyati. (2016). Pengaruh Citra Merek dan Persepsi Biaya Pendidikan terhadap Minat Melanjutkan Studi. Jurnal Pendidikan Akuntansi Indonesia. Vol. 14 No. 1.

Kelvin. (2018). Analisis Pengaruh Promosi, Biaya Studi, Fasilitas Perkuliahan, dan Kualitas Pelayanan terhadap Keputusan Mahasiswa Untuk Kuliah di Sekolah Tinggi Teknik Surabaya. Jurnal Manajemen Kinerja. Vol. 4 No. 1.

Kirom, Bahrul. H. (2012). Mengukur Kinerja Pelayanan dan Kepuasan Konsumen. Jakarta : Pustaka Al-Fikriis.

Kismono, Gugup. (2001). Bisnis Pengantar. Yogyakarta : BPFE. Kotler, Philip dan Keller. 2013. Manajemen Pemasaran. Jilid 1. Edisi 13 . Jakarta : Erlangga.

Laksana, Fajar. (2008). Manajemen Pemasaran. Yogyakarta : Graha Ilmu.

Lamb, Hair, McDaniel. (2001). Pemasaran. Buku 1 Jakarta : Salemba Emban Raya.

Lupiyoadi, Rambat. (2014). Manajemen Pemasaran Jasa. Edisi 3. Jakarta : Salemba Empat.

Lovelock. C, dan John Wirtz. (2011). Pemasaran Jasa Perspektif. Edisi 7. Jakarta : Erlangga.

Malau, Harman. (2016). Manajemen Pemasaran. Bandung : Alfabeta.

Nitisusastro, Mulyadi. (2012). Perilaku Konsumen dalam Perspektif Kewirausahaan. Bandung : Alfabeta.

Romdonny, J. (2019). Factors Affecting Customer Loyalty in Products. Budapest International Research and Critics Institute (BIRCI-Journal). p. 337-343.

Rahma, Eva Seila. (2007). Analisis Pengaruh Kualitas Layanan dan Citra Merek terhadap Minat Beli dan Berdampak pada Keputusan Pembelian. Jurnal Manajemen Bisnis. Universitas Diponegoro.

Santoso,S. (2000). Buku Latihan SPSS Statistik Parametrik. Jakarta: PT. Elex Media Komputindo.

Sekaran, Uma. (2014). Metodologi Penelitian untuk Bisnis. Jakarta: Salemba Empat.

Setiadi, Nugroho J. (2003). Perilaku Konsumen. Jakarta: Kencana.

Sinulingga, Sukaria. (2012), Metode Penelitian. Edisi Kedua. Medan: USU Press.

Soedjas, Triwibowo. (2014). Layanan WOW untuk Pelanggan. Yogyakarta: Media Pressindo.

Stanton, William J. (2005). Prinsip Pemasaran. Jilid 1. Edisi Ketujuh. Jakarta: Erlangga.

Sugiyono. (2008). Metode Penelitian Bisnis. Cetakan Ke-16. Bandung: Alfabeta.

Suliyanthini, Dewi. (2015). Effect of Campus Promotion, Service Quality and Applicants' Image toward Their Decision in Choosing a Higher Education Institution. American Journal of Educational Research. Vol. 3 No. 2. 